\title{
Comparison of organoleptic, protein, lipid and flavonoid content of commercial starter and isolated culture red dragon fruit peel yogurt
}

\author{
Mardiana, Budiono, I. and ${ }^{*}$ Putriningtyas, N.D. \\ Nutrition, Department of Public Health, Faculty of Sport Sciences, Universitas Negeri Semarang, Jl. \\ Sekaran Gunungpati, Semarang, Indonesia
}

\begin{abstract}
Article history:
Received: 12 November 2019

Received in revised form: 10 January 2020

Accepted: 15 January 2020 Available Online: 22

February 2020
\end{abstract}

\section{Keywords:}

Yogurt,

Red dragon fruit peel,

Organoleptic properties,

Flavonoid,

Lactobacillus bulgaricus

DOI:

https://doi.org/10.26656/fr.2017.4(3).380

\begin{abstract}
Red dragon fruit peel can be processed into yogurt. Yogurt is a coagulated milk product obtained from the lactic acid fermentation-yogurt made from various milk, whether fresh milk, skim milk, or even full cream milk. The additions of red dragon fruit peel may enhance the taste and the therapeutical values. This study was aimed to compare the organoleptic properties, protein, lipid, and flavonoid content of commercial starter and isolated culture red dragon fruit peel yogurt. Red dragon fruit peel yogurt was made with amounts of red dragon fruit peel $(25 \% \mathrm{w} / \mathrm{v})$, full cream milk, sucrose and, commercial starter (Lactobacillus bulgaricus, Lactobacillus acidophilus, Streptococcus thermophilus, Bifidobacterium) or isolated culture (L. bulgaricus and S. thermophilus). Hedonic scale test form was used for measuring organoleptic properties. Protein content was used Kjeldahl method, lipid content was used Soxhlet method, and flavonoid content was used chromatography. This research showed that protein and lipid contents in red dragon fruit peel yogurt with commercial starter were higher than red dragon fruit peel yogurt with isolated culture. Flavonoid content in the isolated culture yogurt was higher than commercial starter yogurt. Organoleptic properties between groups were significantly different $(\mathrm{p}<0.05)$. Red dragon fruit peel yogurt used isolated culture has a good chance of getting a positive reception from the public and has potential as a functional food.
\end{abstract}

\section{Introduction}

Dragon fruit plants originated from Central America (Jaya, 2010). Dragon fruit comes from tropical climates and is influenced by air humidity, temperature, soil condition, and rainfall. Dragon fruit is a fruit plant that has been cultivated in Indonesia since 2000 (Jafaar et al., 2009; Jaya, 2010). Dragon fruit has good potential in terms of increasing demand with a variety of cultivation techniques that are easy to do. Dragon fruit has high productivity that affects its availability. The high availability of dragon fruit gives a lot of dragon peel waste. Dragon fruit peel has $30-35 \%$ of the weight of the fruit and has not been used optimally. Dragon fruit peel has the potential to be developed into functional food (Jafaar et al., 2009).

Red dragon fruit peel contains polyphenol compounds and other active compounds, such as alkaloids, terpenoids, flavonoids, phenolic, carotene, and various other vitamins (niacin, thiamine, pyridoxine, cobalamin) (Wu et al., 2006). Dragon fruit peel is a source of natural antioxidants because of the levels of polyphenols (Wu et al., 2006; Nurliyana et al., 2010).
The antioxidants activity in the red dragon fruit peel has higher than the antioxidant activity in the flesh of the fruit. The research showed that in $1 \mathrm{mg} / \mathrm{mL}$, dragon fruit peels could inhibit $83.84 \%$ of free radicals. The red dragon fruit flesh can only inhibit free radicals $27.45 \% / 1$ $\mathrm{mg}$. The super red dragon fruit peel has a percentage of DPPH free radical at 79.24\% (Wiset et al., 2012).

The red dragon fruit peel used as a food color, and even textiles and extracts were taken as a source of natural antioxidants. Another processed form of red dragon fruit peel was processed into beverages. Yogurt can be an alternative to dragon fruit peel diversification. The red dragon fruit peel used as yogurt was expected to increase the economic value and as an alternative functional food(Untari et al., 2014). Yogurt can have various forms such, as semi-solid and liquid forms (Adolfsson et al., 2004; Kolapo and Olubamiwa, 2012). Yogurt is a probiotic drink that has been proven to have health benefits. The red dragon fruit peel yogurt was made through the addition of lactic acid bacteria (Zainoldin and Baba. 2009; Septiana and Ardiaria, 2016; Wahdaningsih and Untari, 2016). Lactic acid bacteria 
that are commonly used are the Lactobacillus and Streptococcus groups. These function of lactic acid bacteria during the fermentation process by converting lactose to lactic acid in the manufacture of red dragon fruit peel yogurt (Kim et al., 2011; Scavuzzi et al., 2014). Taste, flavor, and texture are the primary keys to made yogurt. Several types of bacteria will affect the taste and flavor of yogurt. The distinctive taste and flavor of yogurt can be produced by mixing the bacteria. One of the objectives of this research to compare red dragon fruit peel yogurt used commercial starters (L. bulgaricus, L. acidophilus, S. thermophilus, Bifidobacterium) to isolated culture (L. bulgaricus and S. thermophilus).

\section{Materials and methods}

This research was conducted in June - August 2019. The formulation for the red dragon peel yogurt was defined in the Nutrition Laboratory of the Universitas Negeri Semarang. Laboratory of Environmental Health, Department of Public Health, Universitas Negeri Semarang as a place for making a red dragon peel yogurt starter. Proximate analysis content measurement was performed in the Chemistry Laboratory, Center for Food and Nutrition Studies, Gajah Mada University and Fisheries Product Quality Testing Laboratory, Maritime Affairs, and Fisheries Semarang. Flavonoid content measurement was performed in the Food Technology Laboratory, UNIKA Soegijapranata Semarang. Isolate $L$. bulgaricus and $S$. thermophillus obtained from Microbiology Laboratory, Center for Food and Nutrition Studies, Gajah Mada University. Ethical clearance has been obtained before the study is carried out with the number 140/KEPK/EC/2019.

\subsection{Preparation of isolated starter culture}

An isolated starter culture which contains $L$. bulgaricus and $S$. thermophillus. Pasteurized full cream milk was heated to $75-85^{\circ} \mathrm{C}$ for 15 minutes. $L$. bulgaricus and $S$. thermophillus, respectively, were mixed thoroughly with the preheated milk followed by incubation for $18 \mathrm{hrs}$ at $42^{\circ} \mathrm{C}$. The yogurt formed was stored at $4^{\circ} \mathrm{C}$ and used as a starter culture within 14 days.

\subsection{Preparation of red dragon fruit peel yogurt}

Yogurt A was made by a commercial starter. Pasteurized full cream milk was heated to $75-85^{\circ} \mathrm{C}$ for 15 mins. A mixture of probiotic by Diamond Cold Storage (which contains L. bulgaricus, L. acidophilus, $S$. thermophillus, Bifidobacterium). Yogurt was made by mixing $10 \mathrm{~mL}$ commercial starter with $100 \mathrm{~mL}$ of preheated milk. Red dragon fruit peel was steamed for 15 mins to remove the skin's distinctive aroma and reduce the content of pectin in the peel's red dragon fruit. Red dragon fruit peel $(25 \% \mathrm{w} / \mathrm{v})$ was made by adding $25 \mathrm{~g}$ of gently mashed fruit into $100 \mathrm{~mL}$ of preheated milk. The sucrose for the yogurt was corrected by adding $10 \mathrm{~g}$ for every $100 \mathrm{~mL}$ preheated milk used. After $7 \mathrm{hrs}$ of incubation at $42^{\circ} \mathrm{C}$, the yogurt formed was stored at $4{ }^{\circ} \mathrm{C}$.

Yogurt B was made by mixing $5 \mathrm{~mL}$ of $L$. bulgaricus starter culture and $5 \mathrm{~mL}$ of $S$. thermophillus starter culture with $100 \mathrm{~mL}$ of preheated milk. Fresh red dragon fruit peel is separated from the flesh of the fruit and cleaned using running water. Red dragon fruit peel was steamed for 15 mins to remove the skin's distinctive aroma and reduce the content of pectin in the peel's red dragon fruit. Red dragon fruit peel $(25 \% \mathrm{w} / \mathrm{v})$ was made by adding $25 \mathrm{~g}$ of gently mashed fruit into $100 \mathrm{~mL}$ of preheated milk. The sucrose for the yogurt was corrected by adding $10 \mathrm{~g}$ for every $100 \mathrm{~mL}$ preheated milk used. After 7 hours of incubation at $42^{\circ} \mathrm{C}$, the yogurt formed was stored at $4^{\circ} \mathrm{C}$.

\subsection{Sample preparations}

Yogurt sample was mixed with $2.5 \mathrm{~mL}$ distilled water then incubated at $45^{\circ} \mathrm{C}$ for 10 mins.

\subsection{Flavonoid content}

Homogenized yogurt water extract $(1 \mathrm{~mL})$ was transferred into a test tube and mixed with $1 \mathrm{~mL}$ of $95 \%$ ethanol and $5 \mathrm{~mL}$ of distilled water. To each sample, 0.5 $\mathrm{mL}$ of $50 \%(\mathrm{v} / \mathrm{v})$ Folin- Ciocalteu reagent was added and mixed. After 5 mins, $1 \mathrm{~mL}$ of $5 \% \mathrm{Na}_{2} \mathrm{CO}_{3}$ was added, and the reaction mixture was allowed to stand for 60 mins. The absorbance was read at $725 \mathrm{~nm}$, and the values were converted to total phenolic, expressed in micrograms.

\subsection{Organoleptic properties}

Organoleptic properties were assessed by a panel of untrained individuals, as much as twenty people, in the Nutrition Laboratory and Chemistry Laboratory Food and Nutrition Centre at Gajah Mada University. They consist of eight females and twelve males. All criteria evaluated were given a score of 1-4 points. Organoleptic tests used a hedonic scale from dislike extremely to like extremely. Criteria included aroma, taste, body texture, color, and visual appearance.

\subsection{Water content}

Water content determination was the gravimetric method with oven drying. This method involved weighing a homogenized yogurt, oven drying $100-105^{\circ} \mathrm{C}$ for $3 \mathrm{hrs}$, reweighing, and calculating the mass of water lost as a percentage of the mass of the dried sample. Results are usually reported as \% sample water on a dry- 
mass basis.

\subsection{Ash content}

Ash refers to the inorganic residue remaining after either ignition or complete oxidation of organic matter in the food sample. Determining the ash content of a food is part of proximate analysis for nutritional evaluation, and it is an important quality attribute for some food ingredients.

The gravimetric method was made for the determination of ash content on red dragon fruit peel yogurt. The sample is ashed at $600-650^{\circ} \mathrm{C}$ to constant weight and, the ash is determined by weighing. This method used the dry ashing technique with a muffle furnace to determine the ash content of the sample.

\subsection{Protein content}

Protein content in red dragon fruit peel yogurt was assessed by the Kjeldahl method. In the Kjeldahl procedure, after digestion in concentrated sulfuric acid, the total organic nitrogen is converted to ammonium sulfate. Ammonia is formed and distilled into a boric acid solution under alkaline conditions. The borate anions formed are titrated with standardized hydrochloric acid, which is calculated as the content of nitrogen representing the amount of crude protein in the sample.

\subsection{Fat content}

The soxhlet method described for crude fat analysis on red dragon fruit peel yogurt. The organoleptic properties were analyzed using the Mann- Whitney test and $\mathrm{p}$-value of less than 0.05 were considered statistically significant.

\section{Results and discussion}

Table 1 shows the organoleptic properties of yogurt from two formulations. Panelists preferred group B compared to group A. The intended organoleptic properties include aroma, taste, body texture, color, and visual appearance. The bright pink color is more visible in group B with a thick texture typical of yogurt. The aroma and taste produced by yogurt in group B are not very flavorful and sour. In this research, the red dragon fruit peel was steamed 15 mins. Chan and Choo (2013) found that low temperatures might insufficient for the hydrolysis of protopectin (the insoluble form of pectin) by acids, which leads to a lower yield of pectin. Pectin consists essentially of galacturonic acid residues linked by bonds $\alpha$ (1-4) partially acetylated or esterified by methyl groups, which confer gelling, thickening, stabilizing properties, and has a great water holding (Fishman et al., 2000; Arioui et al., 2017).

Table 2 shows the differences between group A and group B. These differences include aroma, taste, body texture, color, and visual appearance flavor. Research conducted by Settachaimongkon et al. (2014) reported that protocooperation between $S$. thermophillus is one of the important factors that play a role in the fermentation process and the quality of yogurt. The association between the two yogurt lactic acid bacteria (LAB) $S$. thermophilus and L. bulgaricus is regarded as a protocooperation because it is beneficial for both species, but each bacterium can grow alone in milk (Tamime and Robinson, 1999; Rul, 2017) This protocooperation has industrial importance because it can improve yogurt's properties, such as the texture via exopolysaccharide production and the flavor via the production of aromatic compounds (Rul, 2017). Yogurt is a form of milk processing product that utilizes microbes in the fermentation process of fresh milk into a form of semisolid emulsion products with a more acidic taste. Lactic acid bacteria have the potential to be anticholesterol due to exopolysaccharide (EPS) (Horiuchi and Sasaki, 2012). Hydrolysis of lactose to lactic acid by microbial activity increases milk acidity resulting in the coagulation of milk protein and yogurt having an acidic taste.

Table 1. Frequency distribution of organoleptic properties red dragon peel yogurt

\begin{tabular}{lccccc}
\hline \multirow{2}{*}{ Groups } & \multicolumn{5}{c}{ Frequency Distribution of Organoleptic Properties } \\
\cline { 2 - 5 } & Aroma & Taste & Body Texture & Color & Overall \\
\hline A & \multicolumn{5}{c}{0} \\
\hline Dislike extremely & $4(20 \%)$ & $0(0 \%)$ & $1(5 \%)$ & $0(0 \%)$ & $0(0 \%)$ \\
Dislike & $13(65 \%)$ & $9(45 \%)$ & $13(65 \%)$ & $7(35 \%)$ & $12(60 \%)$ \\
Like & $3(15 \%)$ & $11(55 \%)$ & $5(25 \%)$ & $10(50 \%)$ & $8(40 \%)$ \\
Like extremely & $0(0 \%)$ & $0(0 \%)$ & $1(5 \%)$ & $3(15 \%)$ & $0(0 \%)$ \\
\hline B & & & & \\
\hline Dislike extremely & $0(0 \%)$ & $0(0 \%)$ & $0(0 \%)$ & $0(0 \%)$ & $1(5 \%)$ \\
Dislike & $1(5 \%)$ & $3(15 \%)$ & $3(15 \%)$ & $2(10 \%)$ & $1(5 \%)$ \\
Like & $10(50 \%)$ & $9(45 \%)$ & $9(45 \%)$ & $11(55 \%)$ & $10(50 \%)$ \\
Like extremely & $9(45 \%)$ & $8(40 \%)$ & $8(40 \%)$ & $7(35 \%)$ & $8(40 \%)$ \\
\hline
\end{tabular}

A: red dragon peel steamed, full cream milk, sucrose, commercial starter; B: red dragon peel steamed, full cream milk, sucrose, isolated culture 
Table 2. Difference mean

\begin{tabular}{cccccc}
\hline \multirow{2}{*}{ Groups } & \multicolumn{5}{c}{ Mean Rank } \\
\cline { 2 - 6 } & Aroma & Taste & Body & Color & Overall \\
\hline A & 11.73 & 15.3 & 14.15 & 17.08 & 14.2 \\
B & 29.28 & 25.7 & 26.85 & 23.93 & 26.8 \\
$p$ & $0.001 *$ & $0.002 *$ & $0.001 *$ & $0.042 *$ & $0.001 *$ \\
\hline
\end{tabular}

A: red dragon peel steamed, full cream milk, sucrose, commercial starter; B: red dragon peel steamed, full cream milk, sucrose, isolated culture, $p^{*}$ significant, mann-whitney test

The texture of yogurt is strongly influenced by various solids, which are the result of the fermentation process (Widiyaningsih, 2011; Scavuzzi et al., 2014). Red dragon fruit peel yogurt in this study used $L$. bulgaricus and $S$. thermophilus due to a symbiotic relationship between the two lactic acid bacteria and can reduce fermentation time. The growth and stimulation of L. bulgaricus can be stimulated by the production of formic acid, pyruvic acid, and carbon dioxide produced by $S$. thermophillus. The growth of $S$. thermophillus is stimulated by free amino acids and peptides derived from milk production by L. bulgaricus (Settachaimongkon et al., 2014). This is said to be the synbiotic fermentation relationship. The second growth of lactic acid bacteria is homofermentative so that the acid can be produced faster. The homofermentative bacteria, L. bulgaricus and $S$. thermophilus, which produce lactic acid starting from lactose milk (Arioui et al., 2017). The fermentation process results in increased microbial activity, a decrease in $\mathrm{pH}$, and an increase in acid levels in the fermentation product. The fermentation process can improve organoleptic quality and nutritional value, including improving the quality of protein and its digestive value (Horiuchi and Sasaki, 2012; Untari et al., 2014; Settachaimongkon et al., 2014).

Yogurt is viewed as a highly nutritious dairy food product due to levels of protein, lipid, and flavonoid (Widiyaningsih, 2011; Bintari et al., 2017). Table 3 shows the analysis component yogurt $\mathrm{A}$ and yogurt $\mathrm{B}$. The content of ash, lipid and protein in yogurt A were greater than yogurt $\mathrm{B}$. The ash, lipid and protein content in yogurt A, respectively $0.95 \% ; 4.37 \% ; 2.85 \%$. Yogurt has highly attractive nutritional properties- it is low in calories but contains enough macro and micronutrients (proteins, fatty acids, calcium, phosphorus, and vitamins) to cover a person's daily needs (Rul, 2017). Yogurt's lactic acid bacterial cultures can also improve digestive conditions, including gut microflora growth, bowel transit time, and immune response in the alimentary tract (Bintari et al., 2017; Putriningtyas and Wahyuningsih, 2017). Flavonoid content showed an increased level in group B. Table 3 shows the flavonoid content in yogurt
$\mathrm{B}$ has $16.6 \%$ and yogurt $\mathrm{A}$ has $15 \%$.

Flavonoid is bioactive phenols commonly found in fruits, vegetables, and parts of plants. Phenolic and polyphenolic compounds constitute the main class of natural antioxidants present in plants (Wu et al., 2006). Fermentation increases antioxidant activity and, thus, the functional value of the foodstuff. Table 3 shows that group B has higher flavonoid content than group A. Polyphenolic flavonoids display strong antioxidant activity. The flavonoid and lactic acid bacteria content in yogurt gives it potential as a functional food product. Flavonoids have antioxidant activity that can help protect against free radicals and prevent clinical complications from metabolic diseases, such as diabetes mellitus, dyslipidemia, and metabolic syndrome(Galleano et al., 2012; Babu et al., 2013; Jakobsdottir et al., 2014). The addition of dragon fruit increased the total phenolics content in yogurt compared to plain yogurt based on previous research (Zainoldin and Baba, 2009). This might be due to the addition of dragon fruit that contains high phenolic compounds such as phenolic acids and polyphenols, which are commonly known to be found in plants.

Table 3. Analysis of components in yogurt

\begin{tabular}{cccccc}
\hline \multirow{2}{*}{ Groups } & \multicolumn{5}{c}{ Nutrition } \\
\cline { 2 - 6 } & $\begin{array}{c}\text { Water } \\
(\%)\end{array}$ & $\begin{array}{c}\text { Ash } \\
(\%)\end{array}$ & $\begin{array}{c}\text { Lipid } \\
(\%)\end{array}$ & $\begin{array}{c}\text { Protein } \\
(\%)\end{array}$ & $\begin{array}{c}\text { Flavonoid } \\
(\%)\end{array}$ \\
\hline A & 79.81 & 0.95 & 4.37 & 2.85 & 15 \\
B & 80.65 & 0.63 & 2.11 & 2 & 16.6 \\
\hline
\end{tabular}

A: red dragon peel steamed, full cream milk, sucrose, commercial starter; B: red dragon peel steamed, full cream milk, sucrose, isolated culture

This study shows that yogurt can be used to create a nutritious and healthy beverage. The red dragon fruit peel yogurt is suitable for consumption not only by healthy people but also by those who have metabolic diseases, such as dyslipidemia and diabetes as it contains flavonoid, fiber, and lactic acid bacteria that could help decrease blood sugar, cholesterol and triglyceride levels (Babu et al., 2013). This study has many limitations that could be improved by further research, especially regarding the safety and recommended dosages for certain health conditions.

\section{Conclusion}

Red dragon fruit peel yogurt used isolated culture has a good chance of getting a positive reception from the public. Red dragon fruit peel yogurt used isolated culture has potential as a functional food because of its high flavonoid content and low lipid content. 


\section{Conflict of Interest}

The authors declare no conflict of interest.

\section{Acknowledgments}

This study received grant funding from Lembaga Penelitian dan Pengabdian (LP2M) Universitas Negeri Semarang budget in 2019.

\section{References}

Adolfsson, O., Meydani, S.N. and Rusell, R.M. (2004). Yogurt and gut function. American Journal of Clinical Nutrition, 80(2), 245-256. https:// doi.org/10.1093/ajen/80.2.245

Arioui F., Saada, D.A. and Cheriguene, A. (2017). Physicochemical and sensory quality of yogurt incorporated with pectin from peel of Citrus sinensis. Food Science and Nutrition, 5(2), 358-364. https:// doi.org/10.1002/fsn3.400

Babu, P.V.A., Liu, D. and Gilbert, E.R. (2013). Recent advances in understanding the anti-diabetic actions of dietary flavonoids. Journal of Nutritional Biochemistry, 24(11), 1777-1789. https:// doi.org/10.1016/j.jnutbio.2013.06.003

Bintari, S.H., Widyastiti, N.S., Putriningtyas, N.D., Hapsari, R. and Nugraheni, K. (2017). Development and properties of tegurt, a yogurt-like tempe product. Pakistan Journal of Nutrition, 16(4), 221-226. https://scialert.net/abstract/?doi=pjn.2017.221.226

Chan, S.Y. and Choo, W.S. (2013). Effect of extraction conditions on the yield and chemical properties of pectin from cocoa husks. Food Chemistry, 141(4), 3752-3758.

j.foodchem.2013.06.097

Fishman, M.L., Chau, H.K., Hoagland, P. and Ayyad, K. (2000). Characterization of pectin, flash-extracted from orange albedo by microwave heating, under pressure. Carbohydrate Research, 323(1-4):126-138. https://doi.org/10.1016/s0008-6215(99)00244-x

Galleano, M., Calabro, V., Prince, P.D., Litterio, M.C., Piotrkowski, B., Vazquez-Prieto, M.A., Miatello, R.M., Oteiza, P.I. and Fraga, C.G. (2012). Flavonoids and metabolic syndrome. Annals of the New York Academy of Sciences, 1259, 87-94. https:// doi.org/10.1111/j.1749-6632.2012.06511.x.

Horiuchi, H. and Sasaki, Y. (2012). Short communication: Effect of oxygen on symbiosis between Lactobacillus bulgaricus and Streptococcus thermophillus. Journal of Dairy Science, 95(6), 2904 -2090. https://doi.org/10.3168/jds.2011-5147

Jafaar, A.R., Abdul Rahman, A.R., Mahmod, N.Z.C. and Vasudevan, R. (2009). Proximate analysis of dragon fruit (Hylecereus polyrhizus). American Journal of Applied Sciences, 6(7), 1341-1346. https:// doi.org/10.3844/ajassp.2009.1341.1346

Jakobsdottir, G., Nyman, M. and Fak, F. (2014). Designing future prebiotic fiber to target metabolic syndrome. Nutrition, 30(5), 497-502. https:// doi.org/10.1016/j.nut.2013.08.013

Jaya, I.K.D. (2010). Morfologi dan fisiologi buah naga dan prospek masa depannya di Indonesia. Crop Argo, 3(1), 44-50. https://cropagro.unram.ac.id/ index.php/caj/article/view/60/47

Kim, H., Choi, H.K., Moon, J.Y., Kim, Y.S., Mosaddik, A. and Cho, S.K. (2011). Comparative antioxidant and antiproliferative activities of red and white pitayas and their correlation with flavonoid and polyphenol content. Journal of Food Science, 76(1), C38-45. https://doi.org/10.1111/j.17503841.2010.01908.x.

Kolapo, A.L. and Olubamiwa, A.O. (2012). Effect of different concentration of coconut milk on the chemical and sensory properties of soy-coconut milk based yogurt. Food and Public Health, 2(4), 85-91. https://doi.org/10.5923/j.fph.20120204.01

Nurliyana, R., Syed Zahir, I., Mustapha Suleiman, K., Aisyah, M.R. and Kamarul Rahim, K. (2010). Antioxidant study of pulps and peels of dragon fruit: A comparative study. International Food Research Journal, 17(2), 367-375. http:// www.ifrj.upm.edu.my/17\%20(02)\%202010/IFRJ2010-367-375\%20Kamarul\%20IIU[1].pdf

Putriningtyas, N.D. and Wahyuningsih, S. (2017). Potensi yogurt kacang merah (Phaseolus vulgaris L) ditinjau dari sifat organoleptic, kandungan protein, lemak dan flavonoid. The Indonesian Journal of Nutrition, 6(1), 37-43. https://doi.org/10.14710/ jgi.6.1.37-43

Rul, F. (2017). Yogurt: microbiology, organoleptic properties and probiotic potential. In Ray, R.C. and Montet, D. (Eds.) Fermented Foods, Part II: Technological Interventions., p. 525. United States: CRC Press.

Scavuzzi, B.M., Henrique, F.C., Miglioranza, L.H.S., Simao, A.N.C. and Dichi, I. (2014). Impact of prebiotics, probiotics and synbiotics on components of the metabolic syndrome. Annals of Nutritional Disorders and Therapy, 1(2), 1009. https:// www.austinpublishinggroup.com/nutritionaldisorders/fulltext/andt-v1-id1009.php

Septiana, W.C. and Ardiaria, M. (2016). Efek pemberian seduhan kulit buah naga merah (Hylocereus polyrhizus) terhadap kadar malondialdehyde (MDA) tikus sprague dawley dislipidemia. Journal of 
Nutrition College, 5(4), 344-352. https:// doi.org/10.14710/jnc.v5i4.16434. [In Bahasa Indonesia].

Settachaimongkon, S., Nout, M.J., Antunes Fernandes, E.C., Hettinga, K.A., Vervoort, J.M., van Hooijdonk, T.C.M., Zwietering, M.H., Smid, E.J. and van Valenberg, H.J.F. (2014). Influence of different proteolytic strains of Streptococcus thermophilus in co-culture with Lactobacillus delbrueckii subsp. bulgaricus on the metabolite profile of set-yogurt. International Journal of Food Microbiology, 177, 29 -36 . https://doi.org/10.1016/ j.ijfoodmicro.2014.02.008

Tamime, A.Y. and Robinson, R.K. (1999). Tamime and Robinson's Yoghurt: Science and technology. $2^{\text {nd }}$ ed. Boca Raton, Florida, USA: CRC Press.

Untari, E.K., Wahdaningsih, S. and Damayanti, A. (2014). Efek fraksi n-heksana kulit Hylocereus polyrhizus terhadap aktivitas katalase tikus stress oksidatif. Pharmaceutical Sciences and Research, 1 (3), 141-153. https://doi.org/10.7454/psr.v1i3.3489. [In Bahasa Indonesia].

Wahdaningsih, S. and Untari, E.K (2016). Pengaruh pemberian fraksi methanol kulit buah naga merah (Hylocereus polyrhizus) terhadap kadar malondialdehid pada tikus (Rattus novergicus) wistar yang mengalami stress oksidatif. Jurnal Pharmascience, 3(1), 45-55. https:// doi.org/10.20527/jps.v3i1.5834. [ [n Bahasa Indonesia].

Widiyaningsih, E.N. (2011). Peran probiotik untuk kesehatan. Jurnal Kesehatan, 4(1), 14-20. [In Bahasa Indonesia].

Wiset, N., Poomsa-ad, N. and Srilaong, V. (2012). Comparisons of antioxidant activity and bioactive compounds of dragon fruit peel from various drying methods. World Academy of Science, Engineering and Technology, 6, 10-29. https://doi.org/10.5281/ zenodo. 1062480

Wu, L., Hsu, H., Chen, Y., Chiu, C., Lin, Y. and Ho, J. (2006). Antioxidant and antiproliferative activities of red pitaya. Food Chemistry, 95(2), 319-327. https:// doi.org/10.1016/j.foodchem.2005.01.002

Zainoldin, K. and Baba, A.S. (2009). The effect of Hylocereus polyrhizus and Hylocereus undatus on physicochemical, proteolysis and antioxidant activity in yogurt. International Journal of Nutrition and Food Engineering, 3(12), 585-590. https:// www.researchgate.net/publication/235697248 